\title{
ANALISIS AKTIVITAS ANTIBAKTERI EKSTRAK DAUN SIRIH HIJAU (Piper betle Linn) PADA HANDSOAP MENGGUNAKAN METODE CAKRAM
}

\author{
Aiga Sheira Rait ${ }^{1 *}$, Nurhasanah ${ }^{1,2}$, Agung Abadi Kiswandono ${ }^{2}$ \\ ${ }^{1}$ Laboratorium Biokimia, Jurusan Kimia, FMIPA, Universitas Lampung \\ ${ }^{2}$ Jurusan Kimia, FMIPA Universitas Lampung \\ Jl. Soemantri Brojonegoro No. 1, Bandar Lampung, 35141, Indonesia
}

\author{
aigasheira1@gmail.com
}

Artikel Info
Diterima
tanggal
02.10 .2021
Disetujui
publikasi
tanggal
20.10 .2021
Kata kunci : B.
subtilis, daun
sirih, E. coli,
handsoap,
isopropil

\section{ABSTRAK}

Sabun cair adalah bahan pembersih berbentuk cair yang ditambahkan surfaktan dan banyak digunakan untuk keperluan manusia. Salah satunya adalah sabun cair cuci tangan atau handsoap digunakan oleh masyarakat untuk membersihkan kulit pada bagian tangan. Penelitian ini bertujuan untuk mempelajari aktivitas antibakteri ekstrak daun sirih hijau pada handsoap. Metode yang digunakan yaitu ekstraksi daun sirih menggunakan pelarut air, uji aktivitas antibakteri, uji variasi konsentrasi, uji variasi lama penyimpanan dan uji ekstrak daun sirih hijau sebagai pengganti isopropil pada handsoap. Pengujian aktivitas antibakteri dilakukan dengan metode cakram. Hasil penelitian menunjukkan bahwa ekstrak daun sirih hijau segar memiliki daya hambat yang paling besar dibandingkan dengan ekstrak daun sirih kering dan ekstrak daun sirih yang disimpan 3 bulan yakni sebesar $10 \mathrm{~mm} /$ disk terhadap B subtilis dan $9 \mathrm{~mm} /$ disk terhadap E. coli. Variasi konsentrasi $100 \%$ menunjukkan daya hambat yang paling besar yakni $9 \mathrm{~mm} /$ disk terhadap B. subtilis dan $10 \mathrm{~mm} /$ disk terhadap E. coli. Variasi lama penyimpanan menunjukkan tidak ditemukannya zona hambat pada masing-masing media uji. Perbandingan ekstrak daun sirih segar 1:10 memiliki daya hambat yang paling besar yaitu $8 \mathrm{~mm} /$ disk terhadap B. substilis dan 9 $\mathrm{mm} /$ disk terhadap E. coli dibandingkan dengan isopropil. Handsoap yang mengandung ekstrak daun sirih hijau segar 1:10 menunjukkan daya hambat yang lebih besar dibandingkan dengan handsoap yang mengandung isopropil yakni sebesar $14 \mathrm{~mm} /$ disk terhadap B. subtilis dan $13 \mathrm{~mm} /$ disk terhadap E. coli.

\section{ABSTRACT}

Liquid soap is a liquid cleaning agent that is added with surfactants and widely used for human purposes. One of them is liquid hand soap used by the community to clean the skin on the hands. This study aims to study the antibacterial activity of green betel leaf extract in hand washing liquid soap. The methods used are betel leaf extraction using water solvent, antibacterial activity test, concentration variation test, storage time variation test and green betel leaf extract test as a substitute for isopropyl in hand washing liquid soap. Antibacterial activity testing was carried out using the disc method. The results showed that fresh green betel leaf extract had the greatest inhibition compared to dried betel leaf extract and betel leaf extract stored for 3 months, which was $10 \mathrm{~mm} /$ disk against $B$. subtilis and $9 \mathrm{~mm} /$ disk against $E$. coli. The concentration variation of $100 \%$ showed the greatest inhibition, namely $9 \mathrm{~mm} / \mathrm{disk}$ against $B$. subtilis and $10 \mathrm{~mm} /$ disk against $E$. coli. Variations in storage time showed no inhibition zone was found in each bacterial media. Comparison of fresh betel leaf extract 1:10 had the greatest inhibition of $8 \mathrm{~mm} /$ disk against $B$. subtilis and $9 \mathrm{~mm} /$ disk against $E$. coli compared to isopropyl. Hand washing liquid soap containing 1:10 fresh green betel leaf extract showed greater inhibition than hand washing liquid soap containing isopropyl, namely $14 \mathrm{~mm} /$ disk against $B$. subtilis and $13 \mathrm{~mm} /$ disk against $E$. coli.

http://dx.doi.org/10.23960/aec.v6.i2.2021.p122-133

Anal.Environ.Chem. 


\section{PENDAHULUAN}

Salah satu tanaman obat yaitu daun sirih hijau telah lama diketahui dan digunakan untuk pengobatan obat batuk, sakit gigi, penyegar dan sebagainya. Bagian-bagian dari tanaman sirih seperti akar, biji dan daun berpotensi untuk pengobatan tetapi yang paling sering dimanfaatkan untuk pengobatan adalah bagian daunnya. Pemanfaatan daun sirih dalam pengobatan tradisional ini disebabkan adanya sejumlah zat kimia atau bahan alami yang mempunyai aktivitas sebagai senyawa antimikroba. Ekstrak daun sirih hijau mengandung beberapa komponen aktif yang mempunyai aktivitas antibakteri, diantaranya adalah safrol dan kavibetol asetat (Arambewella et al., 2005).

Escherichia coli merupakan bakteri gram negatif primer patogen yang merupakan penyebab kedua penyakit infeksi setelah Streptococcus. Meningitis yang disebabkan oleh Escherichia coli menyebabkan kematian pada $20-40 \%$ pada bayi yang terinfeksi. Selain meningitis, diare juga merupakan salah satu penyakit yang disebabkan oleh Escherichia coli (Jafari et al., 2012). Selain Escherichia. coli, bakteri Bacillus subtilis dari famili Bacillaceae juga merupakan penyebab penyakit infeksi dan jumlahnya yang banyak di dalam usus mampu menyebabkan diare yang ditularkan melalui kontaminasi makanan (Rahmaningsih dkk., 2012). Bacillus subtilis menyebabkan penyakit yang membuat fungsi imun seseorang terganggu, misalnya meningitis dan gastroentritis akut (Jawetz et al., 1996).

Sabun adalah kumpulan senyawa yang terdiri dari satu jenis asam amino atau lebih dan mengandung senyawa alkali yang berfungsi untuk mengemulsi kotoran-kotoran berupa minyak ataupun zat pengotor lainnya (Dorlan, 2002). Saat ini, sabun tidak hanya digunakan untuk menjaga kebersihan badan tetapi juga untuk kebersihan tangan. Mencuci tangan dengan sabun lebih efektif dan efisien jika dibandingkan dengan hanya menggunakan air. Hal ini dikarenakan di dalam handsoap terkandung zat-zat yang bersifat bakterisid dan bakteriostatik (Oranusi et al., 2013).

Kandungan sabun salah satunya terdapat zat yang bersifat antibakteri. Antibakteri merupakan zat yang dapat mengganggu pertumbuhan atau bahkan mematikan bakteri dengan cara mengganggu metabolisme mikroba yang merugikan. Mekanisme kerja dari senyawa antibakteri diantaranya yaitu menghambat sintesis dinding sel, menghambat keutuhan 
permeabilitas dinding sel bakteri, menghambat kerja enzim, dan menghambat sintesis asam nukleat dan protein (Arambewella et al., 2005).

Secara umum, metode pengujian antibakteri dapat dilakukan dengan dua metode, difusi dan dilusi. Metode difusi dapat dilakukan dengan beberapa cara, yaitu E-test, disc diffusion, ditch plate dan gradien plate. Pada penelitian ini digunakan metode disc diffusion dan proses ekstraksi daun sirih hijau dilakukan dengan metode perebusan menggunakan pelarut air. Berdasarkan uraian di atas, pada penelitian ini dilakukan pengujian aktivitas antibakteri dari daun sirih hijau dan pengujian daun sirih hijau sebagai pengganti isopropil pada handsoap.

\section{METODE}

\section{Alat dan Bahan}

Alat-alat yang digunakan adalah seperangkat alat gelas, autoclave, inkubator, Laminar Air Flow (LAF), jarum ose, neraca analitik, alumunium foil, hotplate, bunsen, spatula, oven, gelas ukur, labu ukur, mikropipet Eppendorf, penggaris dan pinset.

Bahan-bahan yang digunakan adalah daun sirih kering, ekstrak daun sirih penyimpanan 3 bulan dan daun sirih hijau segar, kertas saring, kertas Whatmann no.42, aquades, media Nutrient Agar (NA), bakteri B. subtilis, bakteri E. coli, chloramphenicol, amoxicillin, texaphone, Sodium Lauryl Sulfate (SLS), $\mathrm{NaCl}$, isopropil, dan MD Caperlan.

\section{Prosedur}

\section{Ekstraksi Daun Sirih Hijau}

Sampel daun sirih terdiri dari 3 jenis, yakni daun sirih kering, ekstrak daun sirih yang telah disimpan selama 3 bulan dan daun sirih hijau segar. Daun sirih kering dihaluskan dengan cara diblender hingga menghasilkan serbuk halus sedangkan untuk daun sirih segar dipisahkan antara daun dan rantingnya kemudian dicuci bersih dan dicacah hingga berbentuk kecil-kecil. Serbuk halus daun sirih kering dan cacahan daun sirih segar masing-masing ditimbang sebanyak 10 gram dan diekstraksi dengan cara direbus dengan menggunakan pelarut air sebanyak $100 \mathrm{~mL}$ selama 15 menit dengan suhu $50{ }^{\circ} \mathrm{C}$ kemudian disaring. 


\section{Uji Aktivitas Antibakteri}

a. Uji Aktivitas Antibakteri Awal

Pada uji aktivitas antibakteri awal, sampel ekstrak daun sirih kering, daun sirih segar, ekstrak daun sirih penyimpanan 3 bulan, kontrol negatif dan kontrol positif amoxicillin (sebagai kontrol positif untuk B. subtilis), chloramphenicol (sebagai kontrol positif untuk E. coli) diambil sebanyak $0,5 \mu \mathrm{L}$ yang kemudian ditotolkan ke paper disk dengan menggunakan pipa kapiler, ditunggu hingga mengering. Paper disk yang telah mengering dimasukkan ke masing-masing cawan petri yang telah berisi media Nutrient Agar (NA) dan suspensi bakteri B. subtilis dan E. coli. Selanjutnya, diinkubasi pada suhu $37{ }^{\circ} \mathrm{C}$ selama 24 jam (Madigan et al., 2003). Zona hambat yang terbentuk berupa zona bening di sekitar cakram disk dihitung dan dinyatakan dalam satuan milimeter (Tokasaya, 2010).

\section{b. Uji Variasi Konsentrasi}

Ekstrak daun sirih segar divariasikan konsentrasi 25\%,50\%, 75\% dengan pengenceran dari $100 \%$. Setiap variasi konsentrasi ekstrak dan kontrol positif diambil sebanyak $0,5 \mu \mathrm{L}$ yang kemudian ditotolkan ke paper disk dengan menggunakan pipa kapiler, ditunggu hingga mengering. Paper disk yang telah mengering dimasukkan ke masing-masing cawan petri yang telah berisi media NA dan suspensi bakteri B. subtilis dan E. coli. Selanjutnya, diinkubasi pada suhu $37{ }^{\circ} \mathrm{C}$ selama 24 jam.

\section{c. Uji Variasi Lama Penyimpanan}

Ekstrak daun sirih disimpan kedalam dua kondisi penyimpanan yang berbeda, yakni di dalam suhu dingin dan dalam suhu ruang. Ekstrak daun sirih yang telah disimpan selama 7 hari dibuat dengan variasi konsentrasi 25\%, 50\%, 75\% dari pengenceran 100\% dan diuji aktivitas antibakterinya dengan cara diambil sebanyak $0,5 \mu \mathrm{L}$ yang kemudian ditotolkan ke paper disk dengan menggunakan pipa kapiler, ditunggu hingga mengering. Kemudian, paper disk yang telah mengering dimasukkan ke masing-masing cawan petri yang telah berisi media NA dan suspensi bakteri B. subtilis dan E. coli. 
d. Uji Perbandingan Sirih Segar (SS) dengan isopropil

Ekstrak sirih segar (SS), isopropil dan kontrol positif diambil sebanyak 0,5 $\mu \mathrm{L}$ yang kemudian ditotolkan ke paper disk dengan menggunakan pipa kapiler, ditunggu hingga mengering. Kemudian, paper disk yang telah mengering dimasukkan ke masing-masing cawan petri yang telah berisi media NA dan suspensi bakteri B. subtilis dan E. coli.

\section{e. Uji Aktivitas Antibakteri Pada Handsoap}

Masing-masing handsoap pada 4 botol diambil sebanyak 0,5 $\mu \mathrm{L}$ yang kemudian ditotolkan ke paper disk dengan menggunakan pipa kapiler, ditunggu hingga mengering. Kemudian, paper disk yang telah mengering dimasukkan ke masing-masing cawan petri yang telah berisi media NA dan suspensi bakteri B. subtilis dan E. coli.

\section{HASIL DAN PEMBAHASAN}

\section{Ekstrak Sampel Daun Sirih}

Daun sirih kering halus yang telah diblender dan daun sirih segar yang daunnya telah dicacah hingga berbentuk kecil-kecil. Tujuan penghalusan sampel daun sirih kering dan pencacahan daun sirih segar bertujuan untuk memaksimalkan penyerapan pada proses ekstraksi dengan metode perebusan. Perebusan hanya dilakukan pada suhu $50^{\circ} \mathrm{C}$ agar zat aktif pada sampel tidak rusak saat perebusan berlangsung. Hasil perebusan disaring menggunakan kertas saring untuk memisahkan filtrat dan residunya dan diperoleh filtrat sebanyak $68 \mathrm{~mL}$ untuk ekstrak daun sirih segar dan $46 \mathrm{~mL}$ untuk ekstrak daun sirih kering. Sampel ekstrak daun sirih dapat dilihat pada Gambar 1.

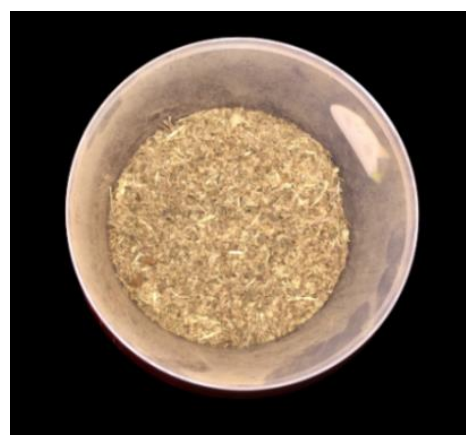

(a)

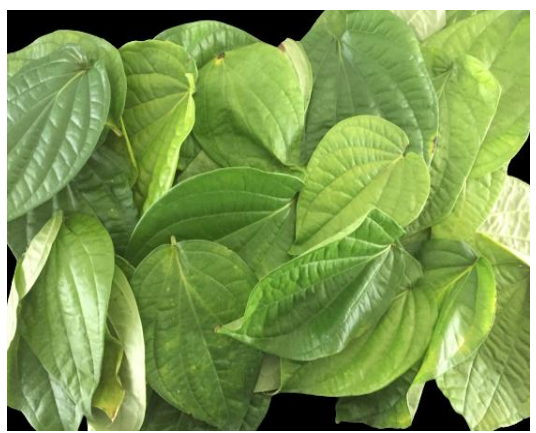

(b)

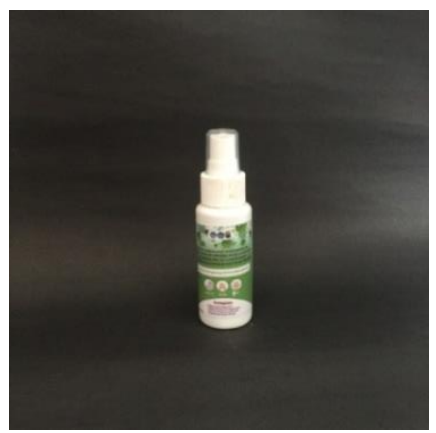

(c)

Gambar 1. (a) daun sirih hijau kering, (b) daun sirih hijau segar, (c) ekstrak daun sirih hijau hasil penyimpanan 3 bulan 


\section{Aktivitas Antibakteri Awal}

a. Uji Aktivitas Antibakteri Awal

Berdasarkan pengujian aktivitas antibakteri yang telah dilakukan, maka didapatkan hasil pengukuran diameter zona hambat $(\mathrm{mm})$ yang ditunjukkan pada Tabel 1. Berdasarkan data pada Tabel 1, pada media bakteri B. subtilis, hasil menunjukkan bahwa ekstrak daun sirih segar (SS) memiliki zona hambat yang paling besar yakni sekitar $10 \mathrm{~mm} /$ disk jika dibandingkan dengan ekstrak daun sirih kering (SK) dan ekstrak daun sirih lama (SL) namun jauh lebih kecil dari kontrol positifnya yaitu amoxicillin. Pada media bakteri E. coli, hasil menunjukkan bahwa ekstrak daun sirih segar (SS) memiliki zona hambat yang paling besar yakni sekitar $9 \mathrm{~mm} /$ disk jika dibandingkan dengan ekstrak daun sirih kering (SK) dan ekstrak daun sirih lama (SL) namun jauh lebih kecil dari kontrol positifnya yaitu chloramphenicol. Diameter zona bening dapat dilihat pada Gambar 2.

Tabel 1. Data aktivitas antibakteri awal

\begin{tabular}{ccc}
\hline \multirow{2}{*}{ Sampel } & \multicolumn{2}{c}{ Diameter zona hambat $(\mathrm{mm})$} \\
\cline { 2 - 3 } & B.subtilis & E.coli \\
\hline SK & 9 & 8 \\
SS & $\mathbf{1 0}$ & $\mathbf{9}$ \\
SL & 8 & 7
\end{tabular}

Kontrol (+): Amoxycilin, chloramphenicol $\quad 28 \quad 29$

Kontrol (-) :

Aquades $\quad 0 \quad 0$

Keterangan: SK (ekstrak daun sirih kering), SS (ekstrak daun sirih segar), dan SL (ekstrak daun sirih lama)

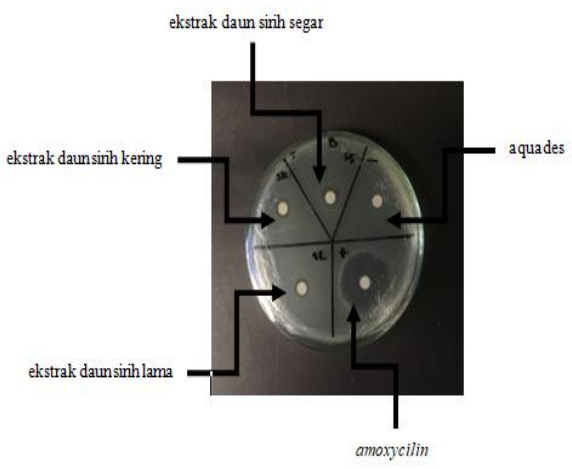

(a)

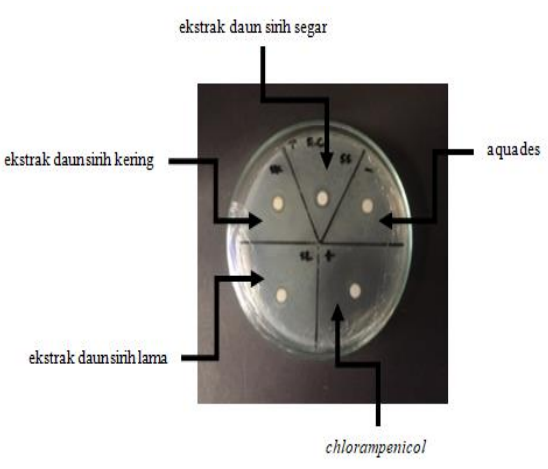

(b)

Gambar 2. (a) media bakteri B. subtilis (b) media bakteri E. coli 
b. Variasi Konsentrasi

Pada pengujian aktivitas antibakteri awal diketahui bahwa daun sirih hijau segar memiliki kemampuan yang paling kuat dalam menghambat bakteri B. subtilis dan E. coli jika dibandingkan dengan daun sirih hijau kering dan ekstrak daun sirih hijau hasil penyimpanan 3 bulan. Selanjutnya, ekstrak daun sirih hijau segar dilanjutkan ke tahap pengujian variasi konsentrasi. Berdasarkan pengujian variasi konsentrasi yang telah dilakukan, maka didapatkan hasil pengukuran diameter zona hambat (mm) yang ditunjukkan pada Tabel 2.

Tabel 2. Data variasi konsentrasi

\begin{tabular}{ccc}
\hline \multirow{2}{*}{ Variasi konsentrasi } & \multicolumn{2}{c}{ Diameter zona hambat (mm) } \\
\cline { 2 - 3 } & B.subtilis & E.coli \\
\hline SS 25\% & 0 & 0 \\
SS 50\% & 4 & 0 \\
SS 75\% & 8 & 8 \\
SS 100\% & $\mathbf{9}$ & $\mathbf{1 0}$ \\
Kontrol (-) : & & \\
Aquades & 0 & 0 \\
\hline
\end{tabular}

Keterangan: SS (ekstrak daun sirih segar)

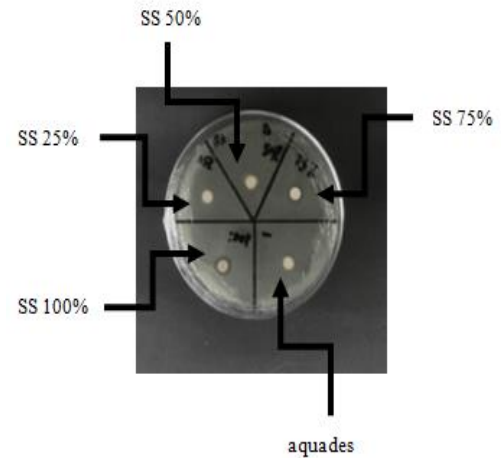

(a)

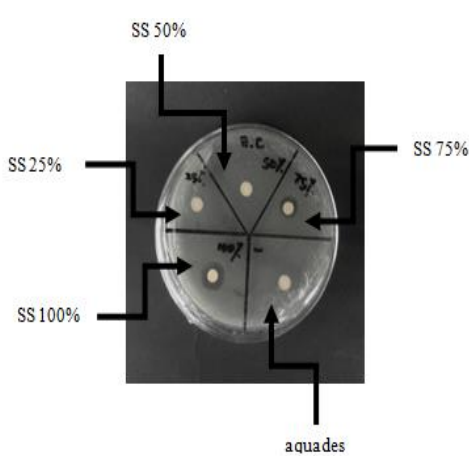

(b)

\section{Gambar 3. (a) media bakteri B. subtilis (variasi konsentrasi) (b) media bakteri E. coli} (variasi konsentrasi)

Berdasarkan data pada Tabel 2, pada media bakteri B.subtilis dan E. coli, hasil menunjukkan bahwa pada konsentrasi $100 \%$ memiliki zona hambat yang paling besar yakni masing-masing sekitar $9 \mathrm{~mm} /$ disk dan $10 \mathrm{~mm} /$ disk dibandingkan dengan konsentrasi 25\%, 50\% dan 75\%.dan pada kontrol negatif aquades tidak memiliki zona hambat. Pada hasil ini, 
konsentrasi $25 \%$ tidak timbul zona hambat dikarenakan zat aktif daun sirih dalam pengenceran tersebut masih terlalu sedikit untuk mampu menghambat pertumbuhan B. subtilis. Zona hambat sudah mulai terlihat pada konsentrasi 50\% dan terus meningkat hingga konsentrasi $100 \%$. Diameter zona bening dapat dilihat pada Gambar 3.

c. Variasi Lama Penyimpanan 1 Minggu

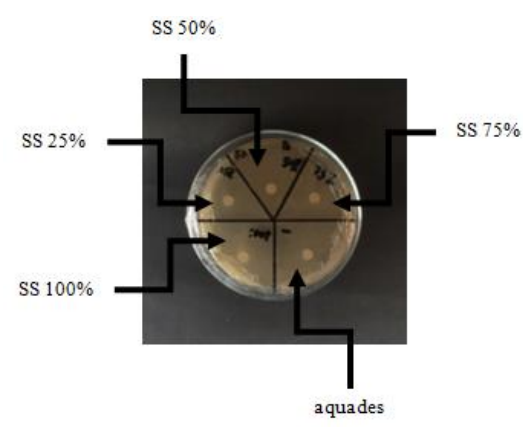

(a)

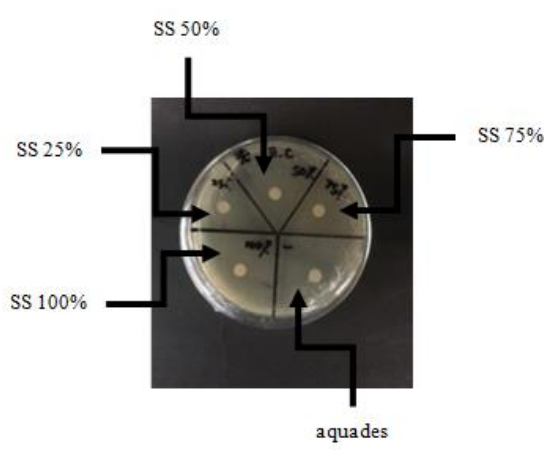

(c)

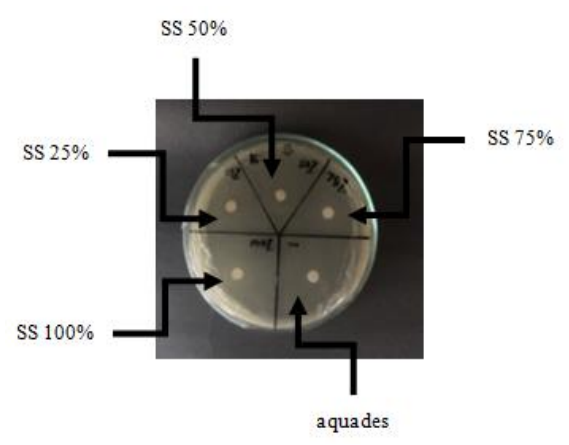

(b)

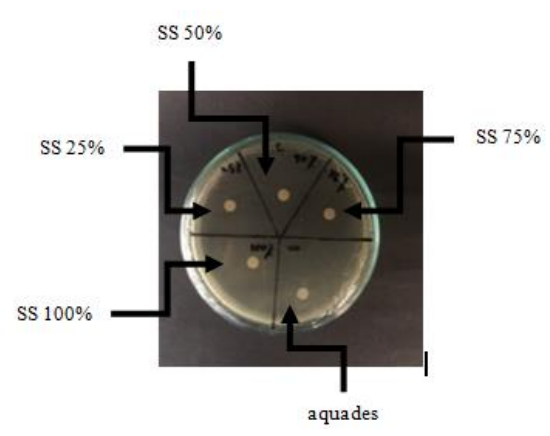

(d)

Gambar 4. (a) media bakteri B. subtilis (suhu ruang) (b) media bakteri B. subtilis (suhu dingin) (c) media bakteri E. coli (suhu ruang) (d) media bakteri E. coli (suhu dingin)

Ekstrak daun sirih segar yang disimpan selama 1 minggu dalam keadaan suhu ruang berwarna kekuningan pekat dan ekstrak daun sirih segar yang disimpan selama 1 minggu dalam keadaan suhu dingin dilakukan pengujian kembali dengan variasi konsentrasi 25\%, 50\%,75\% dari pengenceran $100 \%$. Diameter zona hambat $(\mathrm{mm})$ seperti pada Gambar 4. Berdasarkan Gambar 4, pada media bakteri B.subtilis dan E. coli, hasil menunjukkan bahwa pada berbagai variasi konsentrasi tidak memiliki zona hambat. Hal ini dikarenakan sudah rusak atau hilangnya 
zat aktif pada ekstrak daun sirih yang ditandai dengan tidak munculnya zona hambat pada masing-masing media bakteri.

\section{d. Perbandingan Ekstrak Sirih Segar dengan Isopropil}

Pengujian aktivitas antibakteri selanjutnya ialah pengujian antara ekstrak daun sirih hijau segar dengan isopropil dalam menghambat bakteri B. subtilis dan E. coli. Pengujian perbandingan ini bertujuan untuk mengetahui bagaimana tingkat aktivitas antibakteri dari ekstrak daun sirih hijau segar dan isopropil dalam menghambat bakteri B. subtilis dan E.coli sebelum penambahan handsoap. Pada pengujian perbandingan ekstrak daun sirih segar dengan isopropil yang telah dilakukan, maka didapatkan hasil pengukuran diameter zona hambat (mm) yang ditunjukkan pada Tabel 3.

Tabel 3. Data perbandingan ekstrak daun sirih segar dengan isopropil

\begin{tabular}{ccc}
\hline \multirow{2}{*}{ Variasi konsentrasi } & \multicolumn{2}{c}{ Diameter zona hambat $(\mathrm{mm})$} \\
\cline { 2 - 3 } & B.subtilis & E.coli \\
\hline $\begin{array}{c}\text { SS 1:10 } \\
\text { Isopropil }\end{array}$ & $\mathbf{8}$ & $\mathbf{9}$ \\
$\begin{array}{c}\text { Kontrol (+) : } \\
\text { Amoxicillin, } \\
\text { chloramphenicol }\end{array}$ & 30 & 7 \\
$\quad \begin{array}{l}\text { Kontrol (-) : } \\
\text { Aquades }\end{array}$ & 0 & 29 \\
\hline Keterangan: SS (ekstrak daun sirih segar) & &
\end{tabular}

Berdasarkan data pada Tabel 3, pada media bakteri B. subtilis menunjukkan bahwa ekstrak sirih segar (SS) lebih kuat untuk menghambat pertumbuhan bakteri B.subtilis dengan nilai zona hambat sebesar $8 \mathrm{~mm} /$ disk dibandingkan dengan isopropil yang ditandai dengan perbedaan ukuran zona hambat yang terbentuk namun jauh lebih kecil dibandingkan dengan kontrol positifnya yakni amoxicillin. Pada media bakteri E. coli menunjukkan bahwa ekstrak daun sirih segar (SS) lebih kuat untuk menghambat pertumbuhan bakteri E. coli dengan nilai zona hambat sebesar $9 \mathrm{~mm} /$ disk dibandingkan dengan isopropil yang ditandai dengan perbedaan ukuran zona hambat yang terbentuk namun jauh lebih kecil dibandingkan dengan kontrol positifnya yakni chlorampenicol. Diameter zona hambat dapat dilihat pada Gambar 5. 


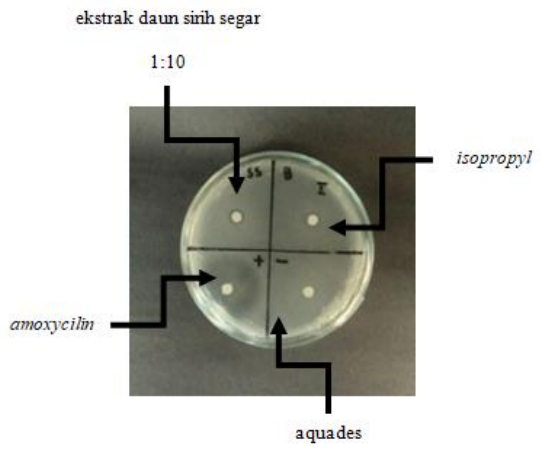

(a)

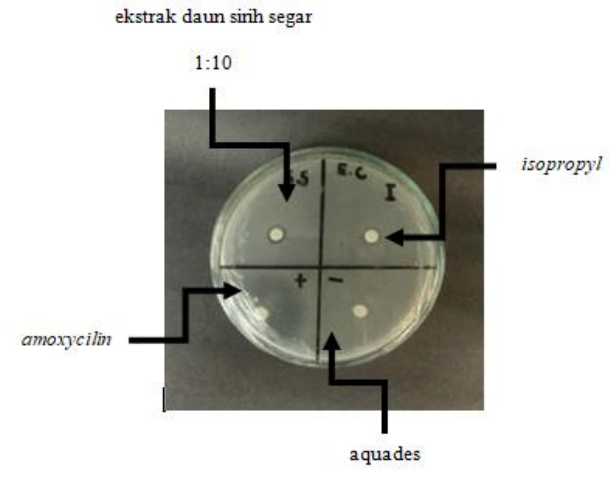

(b)

Gambar 5. (a) media bakteri B. subtilis (b) media bakteri E. coli

\section{e. Aktivitas Antibakteri Pada Handsoap}

Handsoap yang telah ditambahkan ekstrak daun sirih hijau dan isopropil diuji aktivitas antibakterinya. Berdasarkan pengujian aktivitas antibakteri pada handsoap yang telah dilakukan, maka didapatkan hasil pengukuran diameter zona hambat $(\mathrm{mm})$ yang ditunjukkan pada Tabel 4. Berdasarkan data pada Tabel 4, pada media bakteri B. subtilis dan E. coli menunjukkan bahwa sabun cair dengan ekstrak daun sirih segar (SS) konsentrasi 1:10 memiliki zona hambat yang paling besar yakni masing-masing sekitar $14 \mathrm{~mm} /$ disk dan $13 \mathrm{~mm} /$ disk dibandingkan dengan sabun cair campuran lainnya. Diameter zona hambat dapat dilihat pada Gambar 6.

\section{Tabel 4. Data aktivitas antibakteri pada handsoap}

\begin{tabular}{ccc}
\hline \multirow{2}{*}{ Variasi konsentrasi } & \multicolumn{2}{c}{ Diameter zona hambat $(\mathrm{mm})$} \\
\cline { 2 - 3 } & B.subtilis & E.coli \\
\hline SS 1:10 & $\mathbf{1 4}$ & $\mathbf{1 3}$ \\
SS 2:10 & 8 & 7 \\
Isopropil & 10 & 8 \\
(-)I (-)SS & 7 & \\
Kontrol (-) : & & 0 \\
Aquades & 0 &
\end{tabular}




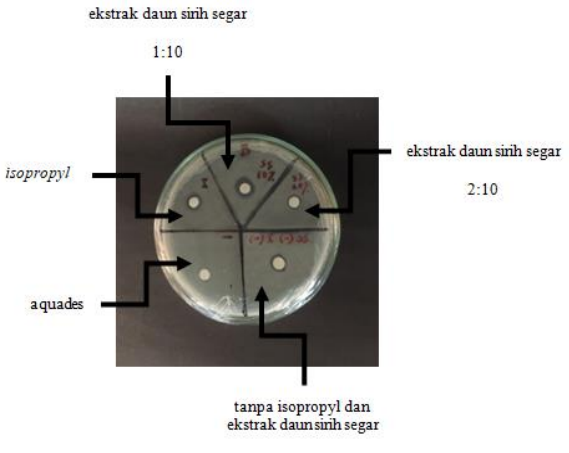

(a)

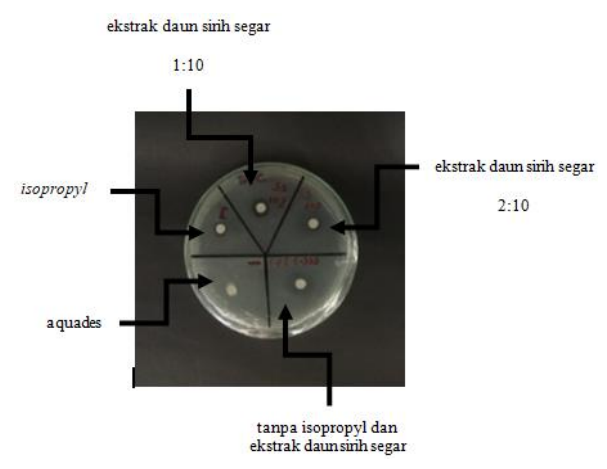

(b)

Gambar 6. (a) media bakteri B. subtilis (a) media bakteri $E$. coli

Beberapa penelitian terkait penggunaan daun sirih hijau sebagai antibakteri juga telah dilaporkan, diantaranya Tirayo et al (2016) mengatakan bahwa sabun cair yang mengandung ekstrak daun sirih hijau mampu menghambat bakteri Escherichia coli sebesar 19-25 mm/disk. Kursia et al (2016) mengatakan bahwa ekstrak etilasetat daun sirih hijau yang di preparasi dengan cara maserasi mampu menghambat bakteri Staphyloccocus epidermis sebesar 9,5-15,5 $\mathrm{mm} /$ disk.

\section{KESIMPULAN}

Ekstrak daun sirih segar (SS) mampu menghambat bakteri B. subtilis dan E. coli masing-masing sebesar $10 \mathrm{~mm} /$ disk dan $9 \mathrm{~mm} /$ disk dibandingkan dengan ekstrak daun sirih kering (SK) dan ekstrak daun sirih lama (SL). Aktivitas antibakteri pada sabun cair memiliki daya hambat paling kuat pada konsetrasi 1:10, yakni sebesar $14 \mathrm{~mm} /$ disk untuk B. subtilis dan 13 $\mathrm{mm} /$ disk untuk E. coli dan dapat digunakan sebagai pengganti isopropil dalam handsoap.

\section{DAFTAR PUSTAKA}

Arambewella, L., Kumaratunga, K. G., and Dias, K., 2005, Studies On Piper Betle of Sri Lanka. J. Natn. Sci. Foundation Sri Lanka., 33(2):133-139.

Dorlan, 2002, Kamus Kedokteran, In EGC, Jakarta.

Jafari, A., Aslani, M., and Bouzari, S., 2012, Escherichia coli a Brief Review of Diarrheagenicpathotypes and Their Role in Diarrheal Diseases in Iran, Iranian Journal of 
Microbiology., 4:102-107.

Jawetz, E., Melnick, J. L., and Adelberg, E. A., 1996, Mikrobiologi Kedokteran (XXII), EGC., Jakarta.

Kursia, S., Lebang, J. S., Taebe, B., Burhan, A., Rahim, dan Nursamsiar., 2016, Uji Aktivitas Antibakteri Ekstrak Etilasetat Daun Sirih Hijau (Piper betle L.) terhadap Bakteri Staphylococcus epidermidis, Indonesian Journal of Pharmaceutical Science and Technology., 3(2):72-77.

Madigan, M., Martinko, J., and Parker, J., 2003, Brock Biology of Microorganism, 10th Edition. Prentice Hall, New Jersey.

Oranusi, S., Oguoma, O., and Agusi, E., 2013, Microbiological Quality Assessment of Foods Sold, Global Research Journal of Microbiology., 3(1):1-7.

Rahmaningsih, S., Willis, S., dan Mulyana, A., 2012, Bakteri Patogen dari Perairan Pantai dan Kawasan Tambak di Kecamatan Jenu Kabupaten Tuban, Ekologia., 1-5.

Tirayo, A., Munir, M dan Hutasoit, G., 2016, The Comparison of Inhibitory Effect Between Antiseptic Soap With Betel Leaf Extract (Piper betle Linn) on The Growth of Escherichia Coli. Ilmiah Kedokteran., 3(3):31-37.

Tokasaya, P., 2010, Sponge Associated Bacteria Producing Antimicrobial Compounds and Their Genetic Diversity Analysis, Bogor Agricultural University, Bogor. 